Methodological thought is working hard on the problem of maintaining a reasonable balance between time-tested ways of acquiring knowledge and formation of verbal skills and mature reforms that require immediate action every day. The teacher of Russian and Ukrainian as foreign languages at the present stage should be mobile, prepared for continuous self-education, able to adapt to any conditions, present themselves, and be competitive in the labor market.

A necessary attribute of modern business relations today is a professional image. It includes a system of individual and professional qualities and competences, among which we put linguistic, methodological and professional-communicative in a special place. Each of them has its own peculiarities in relation to the teaching of Russian and Ukrainian as a foreign language. Without a doubt, psychological and pedagogical competences are also necessary components for teachers of this specialty. Modern ways and methods of their implementation can constitute an interesting vector of further research on this problem.

Key words teacher of higher education, RAL, UAL, traditional and innovative trends, linguistic, methodological and professional-communicative competences.

удк 37.026:37.013:371.134

Олена Ковальова

Льотна академія Національного авіаційного університету

ORCID ID 0000-0001-9238-0466

DOI 10.24139/2312-5993/2020.02/065-076

\title{
ПЕДАГОГІЧНІ УМОВИ ФОРМУВАННЯ ІННОВАЦІЙНОЇ КОМПЕТЕНТНОСТІ МАЙБУТНІХ АВІАЦІЙНИХ ФАХІВЦІВ У ПРОЦЕСІ ВИВЧЕННЯ БЕЗПІЛОТНИХ ПОВІТРЯНИХ СУДЕН
}

Метою дослідження $\epsilon$ обгрунтування педагогічних умов формування інноваційної компетентності майбутніх авіаційних фахівців у прочесі вивчення безпілотних повітряних суден. На основі аналізу наукових досліджень розглянуто поняття «інноваційна компетентність авіаційного фрахівця». Обгрунтовано педагогічні умови формування інноваційної компетентності майбутніх авіаційних фахівців: використання STEM-технології, як опора на принцип єдності теорії та практики, й профресійно-орієнтованого навчання з елементами інноваційної діяльності; організація науково-дослідницької роботи та створення інноваційного середовища для формування інноваційної компетентності майбутніх авіаційних фахівців у процесі вивчення безпілотних повітряних суден.

Ключові слова: інноваційна компетентність, педагогічні умови, авіаційний фахівець, безпілотні повітряні судна, компетенції, інноваційне середовище, інноваційна діяльність, STЕМ-технології.

Постановка проблеми. В Указі Президента України «Про Національну стратегію розвитку освіти в Україні на період до 2021 року» (Указ, 2013) визначено низку проблем національної системи освіти, серед яких одне 3 важливих місць посідає відсутність системи мотивацій і стимулювання інноваційної діяльності, разом із тим зазначається про необхідність відповідності національної системи освіти сучасним інтеграційним і глобалізаційним процесам та вимогам переходу до постіндустріальної цивілізації. Одним із стратегічних напрямів державної політики у сфері освіти обрано розвиток наукової та інноваційної діяльності. 
Особливе місце авіаційної галузі в епоху Четвертої індустріальної революції обумовлено, з одного боку, швидкими темпами технологічного розвитку, значною роботизацією системи управління повітряним судном, з іншого боку - значними темпами зростання кількості авіаперевезень, інтенсифікації повітряного руху, підвищенні вимог до менеджменту авіаційної галузі тощо.

Нові суспільні й економічні виклики, перехід у світ автоматизованих виробництв, цифрового суспільства й інтернету речей вимагає від освітнього процесу формування додаткових компетентностей, які допоможуть авіаційному фахівцю швидко та впевнено реагувати на постійні зміни.

Однією з базових компетентностей авіаційного фахівця в умовах глобалізації світу та Четвертої індустріальної революції ми вважаємо інноваційну компетентність, яка забезпечує ефективність використання нових технологій, здатність до швидкого навчання, високу мотивацію до самоосвіти.

Однак, питання формування інноваційної компетентності фахівця авіаційного профілю в науковій літературі не достатньо висвітлено. Зокрема не розкрито питання педагогічних умов формування інноваційної компетентності майбутніх авіаційних фахівців.

Аналіз актуальних досліджень. Дослідження останніх робіт філософського, педагогічного, психологічного та соціологічного спрямування свідчить про те, що науковці проводять ґрунтовний аналіз проблеми інноваційної компетентності фахівців різних галузей. Найбільшої уваги вона набуває й підлягає широкому висвітленню в контексті формування інноваційної компетентності в освітньому процесі.

Перш ніж розглянути педагогічні умови формування інноваційної компетентності, вважаємо за доцільне зупинитися на визначенні поняття інноваційної компетентності.

Питання «інноваційної компетентності» у своїх дослідженнях розглядали такі науковці як К.Артамонова (Артамонова, 2013), І. Дичківська (Дичківська, 2016), О. Ігнатович (Ігнатович, 2009), Л. Штефан (Штефан, 2010), М. Радченко (Радченко, 2017).

Для розуміння поняття «інноваційна компетенція» цікавою $є$ робота К. Артамонової, яка на основі аналізу різних авторів виокремлює чотири підходи до розгляду змісту і структури інноваційної компетентності (Артамонова, 2013): функціональний (що пов'язаний з практикою побудови й організації освітнього процесу); особистісний («інноваційну компетентність» розглядають насамперед як спосіб самореалізації індивіда); культурологічний (як складний комплекс, що складається з оволодіння різними видами культури. Ключовим фактором $€$ академічна мобільність студентів); віртуальний (який пов'язує формування поняття інноваційної компетентності через організацію віртуального освітнього середовища). Вважаємо за необхідне розглядати «інноваційну компетентність» ураховуючи основні ідеї всіх чотирьох підходів. 
Наукові дослідження, присвячені формуванню компетентностей майбутніх авіаційних фахівців, набувають широкого розгляду. Тільки за останні роки цю проблематику досліджували Т. Плачинда (Плачинда, 2015), Г.Герасименко (Герасименко, 2015), Т. Лаврухіна (Лаврухіна, 2012), Г. Пухальська (Пухальська, 2011), Р. Невзоров (Невзоров, 2019) та інші. Проте питанню формування інноваційної компетентності майбутніх авіаційних фахівців у педагогічних дослідженнях приділено недостатньо уваги.

Стрімкий розвиток безпілотних технологій дозволив розширити сфери їх застосування. Якщо раніше здебільшого йшлося про безпілотні повітряні судна, що використовуються у військовій справі, то тепер можна навести багато прикладів застосування БПС у сільському господарстві, у сфері розваг, у екологічній сфері тощо. Масове використання безпілотних технологій обгрунтовує введення у програму підготовки авіаційних фахівців циклу дисциплін, пов'язаних із застосуванням безпілотних повітряних суден як необхідного елементу фахової підготовки авіаційних фахівців. 3 одного боку, безпілотне повітряне судно є одним із учасників руху в повітряному просторі, а значить, у процесі здійснення професійної діяльності авіаційний фахівець має враховувати нового учасника руху. 3 іншого боку, перспективою недалекого майбутнього є виникнення нової професії авіаційних фахівців дистанційних пілотів безпілотних повітряних суден. Зокрема Державна авіаційна служба України у 2019 році підготувала Зелену книгу «Професія майбутнього: розбудова системи підготовки дистанційних пілотів безпілотних повітряних суден» - документ, що окреслює проблематику сфери, на вирішення якої планується спрямувати відповідну публічну політику (Зелена, 2019). У цьому ж джерелі проаналізовано стрімке зростання показників ринку безпілотних повітряних суден у різних країнах. Зазначається, що «робототехніка та автономні системи, включаючи дрони, мають вирішальне значення для економічного зростання шляхом підвищення рівня продуктивності праці. Як інструмент, який може бути використаний у багатьох секторах, БПС також можуть допомогти вирішити майбутні глобальні виклики людства».

3 іншого боку, у контексті нашого дослідження варто зазначити, що на сьогодні відбувається динамічний розвиток безпілотних технологій, який характеризується швидкими темпами модернізації розробок. Тому вивчення безпілотних повітряних суден, у разі створення необхідних педагогічних умов, може слугувати «полігоном» для реалізації задачі формування інноваційної компетентності майбутніх авіаційних фахівців, оскільки тільки протягом чотирирічного навчання в закладі вищої освіти курсанти стають свідками введення інноваційних розробок у цій сфері, їх модернізації та заміни принципово новими. Наше завдання полягає в обгрунтуванні педагогічних умов, необхідних для формування інноваційної компетентності майбутніх авіаційних фахівців у процесі вивчення безпілотних повітряних суден. 
Різні аспекти педагогічної категорії «педагогічні умови» відображені в багатьох публікаціях дослідників, починаючи з другої половини XX століття, зокрема вивчення робіт О. Федорова, К. Біктагіров, Ю. Юцевич, М. Звєрєва, В. Андреєв, Ю. Бабанський, Є. Яковлєв, Н. Яковлєва, В. Манько, І. Зязюн, О. Бережнова, І. Козловська, М. Козяр, В. Сластьонін, Т. Стефановська, А. Вербицький, В. Загвязинський, В. Полонський, О. Орлов та інших дозволяє всебічно проаналізувати різні трактування поняття «педагогічні умови».

Аналізуючи сутність поняття «педагогічні умови», ми звернулися до дослідження А. Литвина та О. Мацейко (Литвин, 2013, с. 56), які, узагальнюючи низку науково-педагогічних досліджень, пропонують розглядати педагогічні умови як комплекс спеціально спроєктованих генеральних чинників впливу на зовнішні та внутрішні обставини навчальновиховного процесу й особистісні параметри всіх його учасників. На думку авторів, педагогічні умови забезпечують цілісність навчання та виховання в інформаційно-освітньому середовищі закладу освіти відповідно до вимог суспільства й запитів ринку праці, сприяють всебічному гармонійному розвитку особистості та створюють сприятливі можливості для виявлення ії задатків, урахування потреб і формування загальнолюдських і професійно важливих якостей, ключових компетентностей.

Метою статті $\epsilon$ обґрунтування педагогічних умов формування інноваційної компетентності майбутніх авіаційних фахівців у процесі вивчення безпілотних повітряних суден.

Методи дослідження. Для реалізації поставленої мети в роботі були використані такі загальнонаукові методи дослідження, як аналіз, синтез, порівняння та узагальнення.

Виклад основного матеріалу. Ми поділяємо думку науковців про те, що будь-яка компетентність $€$ результатом інтеграції окремих компетенцій, де кожна компетенція відображає певну грань компетентності. Системно інноваційна компетентність авіаційного фахівця розкривається у змісті компонентів, до складу яких включаємо: аксіологічно-мотиваційну, креативну, процесуально-діяльнісну, організаційно-впроваджувальну, соціальну, інформаційно-комунікативну, здоров'язберігаючу, екологічну, рефлексивно-регулятивну компетенції.

Сутність аксіологічно-мотиваційної компетенції полягає в тому, що в авіаційного фахівця повинна бути сформована внутрішня мотивація на інноваційну діяльність, прагнення самореалізації у професійній діяльності, визнання інноваційної діяльності як однієї з основних професійних цінностей.

Креативність - творчий підхід - $€$ рушійною силою будь-якої інноваційної діяльності, що обумовлює виділення цієї компетенції у структурі інноваційної компетентності.

Процесуально-діяльнісна компетенція визначає необхідність оволодіння системою знань щодо інноваційної діяльності та вміння 
застосувати їх на практиці. Вона визначає необхідність оволодіння системою знань щодо інноваційної діяльності та вміння застосувати їх на практиці і включає діагностичні, проєктувальні, конструкторські й організаційні уміння.

Організаційно-впроваджувальна компетенція характеризується вмінням майбутніх авіаційних фахівців аналізувати ефективність тих чи інших існуючих інноваційних технологічних рішень, обирати найбільш ефективні та впроваджувати у своїй діяльності.

Соціальна компетенція включає здатність до групової діяльності та співпраці, готовність прийняти на себе відповідальність за результати праці, здатність до комунікації в мультикультурному середовищі.

Включення до структури інноваційної компетентності інформаційнокомунікаційної компетенції обумовлено тим, що однією з вимог епохи «Четвертої індустрії» $€$ постійне оновлення досягнутого рівня освіти та професійного рівня. Інформальна освіта стає визначальною для професійного успіху фахівця. Особливо актуальною стає ця вимога для авіаційних фахівців, які протягом професійного життя опановують управління низкою повітряних суден, здійснюють свою діяльність в умовах збільшення пасажиропотоку та постійного вдосконалення системи авіаційного менеджменту, удосконалення технологій управління повітряним простором тощо.

Здоров'язбережувальна компетенція обумовлена тим, що в процесі інноваційної діяльності не повинна заподіюватися шкода власному здоров'ю чи здоров'ю оточуючих, а результати втілення інновацій повинні сприяти створенню комфортних умов і збереженню основної головної національної цінності - здоров'я та життя людини.

3 попередньою компетенцією тісно пов'язана екологічна, яка в умовах упровадження концепції сталого розвитку суспільства $є$ основною ціннісною складовою поряд із соціальною та технологічною складовою гармонійного розвитку. Інноваційна діяльність повинна враховувати вимогу екологічності та збереження навколишнього світу, сприяти поліпшенню екології довкілля.

Рефлексивно-регулятивна складова виявляється в контролі, аналізі й оцінці власної інноваційної діяльності, аналізі причин успіхів і невдач, відпрацюванні «роботи над помилками» та зміні неефективних методів діяльності.

Перша педагогічна умова «використання STEM-технології, як опора на принцип єдності теорії і практики та професійно-орієнтованого навчання з елементами інноваційної діяльності» у процесі формальної освіти майбутніх авіаційних фахівців, як у межах однієї дисципліни «Основи керування безпілотними літальними апаратами», так і в міждисциплінарній інтеграції навчальних дисциплін, де розглядаються окремі елементи будови та конструкторських особливостей безпілотних повітряних суден дозволяє формувати всі компетенції інноваційної компетентності. 
Використання STEM-технологій як педагогічної умови формування інноваційної компетентності майбутніх авіаційних фахівців у процесі вивчення безпілотних повітряних суден розглянемо на прикладі проведення лабораторного практикуму з фундаментальної дисципліни, яку вивчають майбутні авіаційні фахівці - «Фізика». Пропонується замість традиційних лабораторних робіт, що виконуються відповідно до змістовних модулів дисципліни «Фізика», упровадити серію лабораторних робіт, які будуть відповідати навчальному матеріалу тих самих змістових модулів, проте їх тематика пов'язана з дослідженням і розробкою функціональних вузлів безпілотних повітряних суден.

Наприклад, виконання лабораторної роботи «Дослідження і розробка силової конструкції квадрокоптеру» у вивченні модуля «Динаміка поступального і обертального руху»; «Дослідження роботи гвинтів» - «Робота і енергія, ККД. Механіка суцільного середовища»; «Дослідження датчика висоти (Дослідження гіроскопа)» - «Атмосферний тиск (Механіка обертального руху)», «Дослідження роботи електричної системи Мультикоптер» - «Електродвигуни та акумулятори Електрика, Магнетизм»; «Вивчення сонару» - «Механічні хвилі. Звук»; «Дистанційне керування і передача відеосигналу» - «Електромагнітні хвилі. Оптика». Особливістю постановки завдання $€$ те, що курсанти не отримують чітких покрокових інструкцій до виконання лабораторної роботи - мають лише методичні рекомендації щодо розробки ходу виконання роботи та детальний опис особливостей обладнання. Подальші дослідження й оформлення результатів курсанти проводять самостійно. Також на завершальному етапі виконання роботи курсант здійснює аналіз особливостей використання досліджуваного елементу як можливої складової безпілотного повітряного судна, спираючись на отримані результату та фізичні закони. У процесі виконання такого роду завдань у майбутніх авіаційних фахівців формуються такі складові інноваційної компетентності, як аксіологічно-мотиваційна, креативна, процесуально-діяльнісна, організаційно-впроваджувальна, інформаційнокомунікативна, рефлексивно-регулятивна компетенції. Разом із цим закладається основа для введення наступної педагогічної умови формування інноваційної компетентності - проєктного навчання.

у процесі вивчення дисциплін «Основи робототехніки», «Програмування робототехнічних систем» та «Основи електроніки та цифрової схемотехніки» за схожими методиками вивчаються електричні й електронні компоненти мультикоптерів і принципи їх функціонування, а також розглядаються можливості побудови різних робототехнічних приставок до безпілотних платформ.

Друга педагогічна умова «організація науково-дослідницької роботи курсантів у процесі професійної підготовки авіаційних фрахівців». Одним з методів формування інноваційної компетентності авіаційних 
фахівців у процесі вивчення безпілотних повітряних суден, який ми використовуємо під час викладання дисциплін «Основи безпілотних літальних апаратів» та «Основи керування безпілотними літальними апаратами» $€$ проєктне навчання. На наш погляд, цей метод дозволяє сформувати всі компетенції, які є складовими інноваційної компетентності.

Передпроєктна підготовка курсантів полягає у формуванні груп для виконання проєкту. Вже на цьому етапі ми починаємо формувати соціальну компетенцію, адже курсантам пропонується об'єднатися у групи з урахуванням рекомендацій соціонічного аналізу (Гуленко, 2003).

Далі курсантам пропонується обрати один із можливих варіантів використання БПС та розробити модель безпілотного повітряного судна мультироторного типу, яка максимально ефективно зможе виконувати обране групою завдання. Для створення моделі курсантам пропонується спочатку сформулювати льотно-технічні характеристики такого судна, які забезпечать виконання проєкту. Після цього курсанти визначають характеристики складових компонентів дрону, формуючи початковий набір компонентів. За допомогою калькулятора для мультикоптерів проводиться оптимізація набору компонентів шляхом аналізу їх льотних характеристик, які автоматично розраховуються у програмі. Запропонована модель має бути презентована і «захищена» перед іншими проєктними групами.

Першим етапом реалізації проєкту $\epsilon$ аналіз існуючих напрямів використання безпілотних повітряних суден, висунення власних ідей щодо нових напрямів використання БПС, формулювання мети та завдань власного проєкту. На етапі обговорення проєкту в курсантів відбувається формування всіх компетенцій, що входять до складу інноваційної компетентності. Аналізуючи вже існуючі в світі приклади використання БПС (формування інформаційно-комунікативної компетенції), здебільшого учасники групи виявляють зацікавлення у створенні власної ідеї або вдосконалення існуючих проєктів (аксіологічно-мотиваційна та креативна компетенції). На цьому ж етапі відбувається розподіл завдань (ролей) усередині групи (формування соціальної компетенції) й окреслення переліку завдань для кожного. Безпосередньо робота над проєктом дозволяє формувати процесуально-діяльнісну, організаційновпроваджувальну, інформаційно-комунікативну, соціальну, здоров'язберігаючу, екологічну та рефлексивно-регулятивну компетенції.

На етапі презентації та «захисту» проєкту відбувається формування інформаційно-комунікативної, соціальної та рефлексивно-регулятивної компетенції.

щоб підвищити ефективність формування інноваційної компетентності в процесі проєктного навчання захист проєкту пропонується проводити у формі ділової гри «Фандрейзінг». Сутність гри полягає в тому, що групи «розробників проєктів» по черзі зустрічаються з групою «інвесторів» i 
презентують свій проєкт з метою отримання «інвестицій». Умовою гри $\epsilon$ обмеженість фінансових ресурсів, які можуть бути вкладені та часу, протягом якого відбувається презентація. «Інвестори» можуть приймати рішення щодо фінансування лише деяких проєктів або часткового фінансування. Використання такої ділової гри моделює реальний шлях просування на ринку інноваційних проєктів (стартапів). Вона є засобом і методом підготовки до професійної діяльності та соціальної взаємодії інноваторів.

Кейс-метод використовується для аналізу готових інноваційних рішень, запропонованих у сфері безпілотних повітряних суден, виявлення основних переваг і недоліків апарату, оцінки соціального значення й екологічності зразка, і навіть напрацюванню пропозицій щодо вдосконалення розробки. Кейси можуть бути представлені у вигляді текстового опису із зазначенням основних параметрів пристрою, або у вигляді відеокейсів - презентацій існуючих моделей. Розбір кейсів може бути індивідуальним або груповим. Може поєднувати ці два види роботи: спочатку кейс аналізується індивідуально, потім результати аналізу обговорюються у групі та пропонується узагальнити напрацювання й представити груповий висновок.

Третя педагогічна умова «створення інноваційного освітнього середовища». Спираючись на думку науковців, під інноваційним освітнім середовищем ми розуміємо педагогічно доцільно організований простір життєдіяльності, який сприяє розвиткові інноваційного ресурсу особистості; інтегрований засіб накопичення і реалізації інноваційного потенціалу закладу освіти (Шапран, 2010, с. 109).

у Льотній академії Національного авіаційного університету інноваційне освітнє середовище, що сприяє формуванню інноваційної компетентності майбутніх авіаційних фахівців, створюється шляхом участі академії в організації Всеукраїнських і Міжнародних наукових конкурсів та хакатонів, Міжнародних науково-практичних семінарів і конференцій, організації роботи інноваційних Центрів, залучення майбутніх авіаційних фахівців до виконання грантових проєктів, мотивації до розробки власних стартапів, заохочення до участі у Світових турнірах з кібер-спорту (дронрейсингу), налагодженні співпраці з провідними вітчизняними й іноземними компаніями, що займаються розробками у сфері БПС, командами, що займаються стартапами у сфері БПС тощо.

Участь майбутніх авіаційних фахівців у таких Всесвітніх хакатонах як Global Game Jam (міжнародний конкурс розробників комп'ютерних ігор, у тому числі тренажерного типу), NASA Space Apps challenge (найбільший міжнародний науковий хакатон Національного управління з аеронавтики та дослідження космічного простору США) дозволяють, з одного боку, подавати на розгляд міжнародного журі свої інноваційні розробки, у тому числі у сфері БПС, а з іншого - знайомитися з «найсвіжішими» світовими розробками й інноваційними проєктами. 
Досвід участі майбутніх авіаційних фахівців у всеукраїнському студентському конкурсі «Авіатор», останній етап якого передбачає розробку та презентацію проєкту на авіаційну тематику, свідчить, низка представлених конкурсних розробок так чи інакше пов'язані з дослідженням безпілотних технологій. Частина з них продовжується в розробках дипломних проєктів і розглядається як ідея майбутнього стартапу.

Щорічний Всеукраїнський науково-практичний семінар із питань упровадження безпілотних технологій, де представлені кращі фахівцірозробники, експлуатанти, фахівці з правового супроводу БПС тощо, дозволяє майбутнім авіаційним фахівцям орієнтуватися в тенденціях розвитку безпілотних технологій в Україні та сприяє формуванню аксіологічно-мотиваційної, креативної, процесуально-діяльнісної, організаційно-впроваджувальної, соціальної, інформаційно-комунікативної, рефлексивно-регулятивної компетенції інноваційної компетентності.

Створення в закладі вищої освіти інноваційних Центрів, як то Центру безпілотних літальних апаратів та Центру робототехніки дозволяє викладачам ефективно використовувати технологію освітнього коучінгу (Парслоу, 2003) - розкриття внутрішнього потенціалу особистості та побудови індивідуальної траєкторії самоосвіти, саморозвитку в напрямі «до успіху». Траєкторії розвитку в межах діяльності в одному центрі можуть суттєво відрізнятися. Наприклад, одні спрямовують свою діяльність на досягнення успіху в кібер-спорті (участь у Міжнародних перегонах спортивних дронів Дрон-Рейсинг). Інші - обирають різного роду волонтерську діяльність: участь у пошуково-рятувальних операціях чи програмах екологічного моніторингу (як оператори БПС); менторську діяльність у програмі «Перепідготовка та соціальна адаптація військовослужбовців та членів їх сімей» (як інструктори 3 використання БПС); волонтерську допомогу в організації різного роду інноваційних заходів. Інші вбачають свій успіх, у тому числі й утілення інноваційних проєктів, у створенні відеопродукту з використанням БПС або ж розробці тренажерів для підготовки оператора БПС тощо.

$\begin{array}{rllll}\text { Важливим } & \text { елементом } & \text { створення } & \text { інноваційного } & \text { освітнього } \\ \text { середовища } \epsilon & \text { створення віртуального } & \text { інноваційного } & \text { освітнього }\end{array}$
середовища як комплексного поєднання комп'ютерних, комунікаційних, мережевих ресурсів, що сприятиме формуванню цілісного уявлення про інновації (у нашому випадку - у сфері безпілотних повітряних суден) та якнайшвидшому обміну інформацією між зацікавленими сторонами. Воно складається з віртуального банку даних (відеконтенту, програмних продуктів, віртуальних тренажерів, презентаційних матеріалів, публікацій з тематики БПС, нормативно-регулятивної документації щодо використання БПС, бази даних партнерських організацій тощо) та формується всіма учасниками навчально-виховного процесу, що задіяні у процесі вивчення БПС, а також партнерськими організаціями, що працюють у сфері 
розробки, випробувань, експлуатації БПС. Використання такого банку даних у поєднанні з можливостями обміну інформацією через соціальні мережі (створення тематичних груп, спеціалізованих уoutube каналів) дозволяє просто обмінюватися інформацією, проводити їі аналіз, оперативно отримувати інформацію про інновації з будь-якої точки земної кулі та залучати до он-лайн обговорення фахівців із різних країн світу, формуючи свої групові рейтинги чи антирейтинги запропонованих рішень.

Висновки та перспективи подальших наукових розвідок. Отже, у результаті дослідження нами визначено педагогічні умови, реалізація яких забезпечить ефективність формування інноваційної компетентності майбутніх авіаційних фахівців у процесі вивчення безпілотних повітряних суден. А саме: використання STEM-технології як опора на принцип єдності теорії і практики та професійно-орієнтованого навчання з елементами інноваційної діяльності; організація науково-дослідницької роботи майбутніх авіаційних фахівців у процесі вивчення безпілотних повітряних суден; створення інноваційного середовища для формування інноваційної компетентності авіаційних фахівців у процесі вивчення безпілотних повітряних суден. Проведене дослідження не вичерпує всіх аспектів проблеми формування інноваційної компетентності майбутніх авіаційних фахівців. Подальшого дослідження потребують такі напрями, як формування інноваційної компетентності майбутніх авіаційних фахівців в умовах діяльності наукових парків і технопарків, а також формування інноваційної компетентності майбутніх авіаційних фахівців в умовах запровадження дуальної освіти в закладах вищої освіти.

\section{ЛІТЕРАТУРА}

Артамонова, Е. М. (2013). Формирование инновационной компетентности педагога в процессе обучения в вузе. Педагогическое образование и наука, 5, 17-26 (Artamonova, E. M. (2013). Formation of teacher's innovative competence in the process of education at the university. Teacher education and science, 5, 17-26).

Герасименко, Г.В. (2015). Формування фрахових компетентностей курсантів льотних навчальних закладів у процесі вивчення фундаментальних дисциплін (автореф. дис. ... канд. пед. наук: 13.00.04). Запоріжжя (Herasymenko, H. V. (2015). Formation of professional competencies in cadet airplane pilots at aviation education institutions during studying fundamental disciplines (PhD thesis abstract). Zaporizhzhia).

Гуленко, В.В. (2003). Менеджмент слаженной команды. Соционика для руководителя. Москва: Астрель (Hulenko, V. V. (2013). Management of a coordinated team. Socionics for the leader. M oscow: Astrel).

Дичківська, І. М. (2016). Інноваційні педагогічні технології. Київ: Академвидав (Dychkivska, I. M. (2016). Innovative pedagogical technologies. Kyiv: Akademvydav).

зелена книга «Професія майбутнього: розбудова системи підготовки дистанційних пілотів БПС. Режим доступу: https://avia.gov.ua/wpcontent/uploads/2019/08/Green-Book-remote-pilots.pdf (Green Paper "The Profession of the Future: Building a Training System for Remote Pilots of Unmanned Aircraft. Retrieved from: https://avia.gov.ua/wp-content/uploads/2019/08/GreenBook-remote-pilots.pdf). 
Ігнатович, О. М. (2009). Психологічні основи розвитку фахової інноваційної культури педагогічних прачівників. Київ: Центр учбової літератури (Ihnatovych, О. М. (2009). Psychological bases of development of professional innovative culture of pedagogical workers. Kyiv: Center for Educational Literature).

Лаврухіна, Т.В. (2012). Формування ключових компетентностей майбутніх авіаційних диспетчерів як умова готовності до професійної діяльності Актуальні проблеми соціології, психології, педагогіки, 16, 168-174 (Lavrukhina, T.V. (2012). Formation of key competencies of future aviation controllers as a condition of readiness for professional activity. Actual problems of sociology, psychology, pedagogy, 16, 168-174).

Литвин, А., Мацейко, О. (2013). Методологічні засади понятя «педагогічні умови». Педагогіка і психологія профресійної освіти, 4, 43-63 (Lytvin, A., Matseiko, 0. (2013). Methodological foundations of the concept of "pedagogical conditions". Pedagogy and psychology of vocational education, 4, 43-63).

Невзоров, Р.В. (2019). Формування фрахової компетентності майбутніх військових пілотів із застосуванням засобів повітряно-тактичної підготовки (автореф. дис. ... канд. пед. наук: 13.00.04). Кропивницький (Nevzorov, R. V. (2019). Formation of professional competence of future military pilots with the use of airtactical training (PhD thesis abstract). Kropyvnytskyi).

Парслоу, Э., Рэй, М. (2003). Коучинг в обучении: практические методы и техники. Санкт Питербург: Питер (Parslow, E., Rey, M. (2003). Coaching in education: practical methods and technology. St. Petersburg: Piter).

Плачинда, Т.С. (2015). Теоретичні і методичні засади забезпечення якості профресійної підготовки курсантів льотних навчальних закладів в умовах євроінтеграції (дис. ... док-ра пед. наук: 13.00.04). Черкаси (Plachinda, T. S. Theoretical and methodological principles of ensuring the quality of professional training of cadet airplane pilots under European integration (DSc thesis). Cherkasy).

Пухальська, Г.А. (2011). Педагогічні умови формування комунікативної компетентності у майбутніх пілотів цивільної авіації (автореф. дис. ... канд. пед. наук: 13.00.04). Черкаси (Pukhalska, Н. A. (2011). Pedagogical conditions for the formation of communicative competence in future civil aviation pilots (PhD thesis abstract). Cherkasy).

Радченко, М.І. (2017). Шляхи формування інноваційної компетентності студентів. Вісник Національного авіаційного університету. Серія: Педагогіка, Психологія. 11, 112116 (Radchenko, M. I. (2017). Ways of formation of innovative competence of students. Bulletin of the National Aviation University. Series: Pedagogy, Psychology, 11, 112-116).

Указ Президента України «Про Начіональну стратегію розвитку освіти в Україні на період до 2021 року» (Presidential Decree "On the National Strategy for the Development of Education in Ukraine until 2021") (2013). Retrieved from: https://zakon.rada.gov.ua/laws/show/344/2013.

Шапран, О.ІІ, Шапран, Ю. П. (2010). Створення інноваційного освітнього середовища в процесі професійної підготовки майбутнього вчителя. Педагогіка, психологія ma медико-біологічні проблеми фрізичного виховання i спорту, 9, 108-110 (Shapran, O. I., Shapran, Yu. P. (2010). Creating an innovative educational environment in the process of future teacher's professional training. Pedagogy, psychology and medical and biological problems of physical education and sports, 9, 108-110).

Штефан, Л. В.(2010). Інноваційна компетентність інженера-педагога. Вісник лнУ імені Тараса Шевченка, III, 22, 245-253 (Shtefan, L. V. (2010). Innovative competence of engineer-teacher. Bulletin of Lugansk Taras Shevchenko National University, Part III, 22, 245-253). 


\section{PEЗЮME}

Ковалева Елена. Педагогические условия формирования инновационной компетентности будущих авиационных специалистов в процессе изучения беспилотных воздушных судов.

Цель - обоснование педагогических условий формирования инновационной компетентности будущих авиационных специалистов в процессе изучения беспилотных воздушных судов (БВС). На основе анализа научных исследований рассмотрено понятие «инновационная компетентность авиационного специалиста». Обоснованы педагогические условия формирования инновационной компетентности будущих авиационных специалистов в процессе изучения БВС: использование STЕМтехнологии как опора на принцип единства теории и практики, профессиональноориентированного обучения с элементами инновационной деятельности; и создание инновационной среды для формирования инновационной компетентности.

Ключевые слова: инновационная компетентность, педагогические условия, авиационный специалист, беспилотные воздушные суда, компетенции, инновационная среда, инновационная деятельность, STЕМ-технологии.

\section{SUMMARY}

Kovalova Olena. Pedagogical Conditions of Formation of Future Aviation Specialist's Innovative Competence in the Process of Unmanned Aircraft Studying.

The article emphasizes that new social and economic challenges, entry into the era of the Fourth Industrial Revolution require from the educational process the formation of additional competencies that will help the aviation specialist to quickly and confidently respond to the constant modernization of aircraft and development of fundamentally new models in the world and be able to innovate. It is noted that the widespread use of unmanned aeronautical technologies in civilian life justifies introduction into the training program of aviation specialists of a discipline related to the use of unmanned aerial vehicles as a necessary element of aviation specialists' professional training. The dynamic development of unmanned technologies, which is characterized by the rapid pace of modernization of developments, encourages the study of unmanned aircraft, in the context of which there is a need to identify and substantiate effective pedagogical conditions, as a basis for realization of the task of forming the innovative competence of future aviation professionals.

On the basis of scientific research, the concept of "innovative competence of aviation specialist" and its elements is considered. The pedagogical conditions are substantiated, implementation of which will ensure the efficiency of formation of future aviation specialists' innovative competence in the process of studying unmanned aerial vehicles and methods and forms of training are given in accordance with certain pedagogical conditions.

Pedagogical conditions that contribute to the formation of innovative competence of future aviation specialists include: the use of STEM technology as a support for the principle of unity of theory and practice and vocational training with the elements of innovation; organization of research work and creation of innovative environment for the formation of innovative competence of future aviation specialists in the process of unmanned aircraft studying.

Further research need such directions as formation of innovative competence of future aviation specialists in the conditions of activity of Science Parks and formation of innovative competence in the conditions of introduction of dual education.

Key words: innovative competence, pedagogical conditions, aviation specialist, unmanned aircraft, competencies, innovative environment, innovative activity, STEM technology. 